\title{
WEB ADVERTISING MESSAGES IN CROATIAN TOURISM: EXPLORING QUALITATIVE AND QUANTITATIVE PERSPECTIVES ${ }^{1}$
}

\author{
Miriam Bait \\ Tea Baldigara \\ Jelena Komšić
}

https://doi.org/10.20867/tosee.26

\begin{abstract}
Purpose - Today's tourism has become a multinational business of global importance, and therefore advertising tourism destinations and national tourism is crucial. Advertising is a tool that can shape the desired image of the destination, building a positive image and reputation of the destination and, consequently, attracting tourists to the destination, helping tourism providers save money and energy. The research aim is twofold: first, to contextualize the research empirical and conceptual contributions in terms of peer-review articles concerning tourism advertising messages; second, to provide insights into the characteristics and the structure of online tourism advertising messages appearing in Croatian tourism websites.

Methodology - The study examines 231 tourism advertising messages available online on official tourist boards of the main Croatian tourist regions. The research methodology consists of both a qualitative and a quantitative analysis. Firstly, discourse analysis was conducted on the collected advertising messages to identify salient linguistic traits; secondly, quantitative as well as sentiment analysis will provide further insight on the most recurring forms and functions together with an evaluation of the impact of the texts on potential tourists.

Findings - The performed qualitative and quantitative analysis confirmed the typical structure and form of advertising messages. However, the sentiment analysis results pointed out that the investigated advertising messages have a rather low impact on tourist and customers. Therefore, to make advertising messages more attractive and catch readers' attention, they should be designed and created with a greater focus on visitors' expectations, desires and needs, so that they could be used as tourism flows redistribution tools.

Contribution - The present paper represents an introductory analysis of the scientific research project ZP UNIRI 4/18 supported by the University of Rijeka and is aimed to contribute to a deeper understanding of online tourism advertising messages on Croatians tourist boards websites, their structure and forms. The research results are to be considered as a prerequisite for further detailed and systematic analyses from a multidisciplinary and multimodal perspective.
\end{abstract}

Keywords Croatian tourism, advertising messages, sentiment analysis, discourse analysis, text analysis

\footnotetext{
${ }^{1}$ This paper is jointly authored, with each author focusing on a specific area of analysis. Tea Baldigara is responsible for overall organisation of the paper, Jelena Komsic for section 1 and 2, and Miriam Bait for section 3 and conclusion.
} 
ToSEE - Tourism in Southern and Eastern Europe, Vol. 5, pp. 31-45, 2019

M. Bait, T. Baldigara, J. Komšić: WEB ADVERTISING MESSAGES IN CROATIAN TOURISM: ...

\section{INTRODUCTION}

Today's tourism has become a multinational business of global importance. Advanced information communication technology in tourism has enabled the creation of useful information databases and big data that impact the field of tourism in many ways. Promoting tourism destinations and national tourism is a crucial tool for destination marketing which builds a positive image and reputation of the destination and tries to modify the travellers' behavior. Therefore, the managers' goal is to attract tourists toward the selected destination, while the goal of the advertising messages is, ultimately and obviously, to sell. According to Salehi \& Farahbakhsh (2014), professional advertising can be seen as a winning tool for the economic development of a given country, while insufficient, inadequate advertising can be a waste of money and energy. In this paper, advertising messages are defined as a mixture of visual, audio and written text aimed at drawing attention and conveying a strong message to the target audiences making use of various linguistic devices (Teodorescu, 2015).

It is a well-known fact that tourism is one of the world's leading economic activities accounting for $30 \%$ of the world's services consumption and $6 \%$ of total goods and services export (www.ira.lib.polyu.edu.hk). In Croatia, tourism and the hotel industry represent significant profit generators and are among the most propulsive economic sectors, steadily contributing to Croatian economic growth and development. Starting from the important role played by tourism and hospitality in the Croatian economy, more detailed and efficient analyses are required by implementing specific and adequate qualitative and quantitative methods and techniques, in order to model and forecast future tourist market features trends and key determinants. The enhancement of Croatian tourism competitiveness is based on a set of policy goals postulated by official institutions and bodies, i.e. profiling Croatia as one of the high-quality tourist destinations in the Mediterranean and Europe, increasing earnings by rising the spending in tourism, to extend the tourist season, and developing sustainable a sustainable and competitive tourism. The achievement of such and other goals asks for a synergic action of all counterparts and stakeholders involved in the tourism sector, but above all it requires accurate and combined qualitative and quantitative analysis, modelling and forecasting. (Baldigara \& Mamula, 2012)

Promoting the tourism and hospitality industry should be a vital element in creating a tourism offer that and can, in a significant extend, contribute to their economic success. Given this framework, the aims of the present paper are to contextualize the research empirical and conceptual contributions in terms of peer-review articles concerning tourism advertising messages, and to provide insights into the characteristics and the structure of online tourism advertising messages appearing in Croatian tourism websites. This paper will serve as as point of reference for tourism and hospitality scholars, researchers and students interested in this topic. The present paper represents an introductory analysis of the scientific research project ZP UNIRI 4/18 supported by the University of Rijeka and is aimed to contribute to a deeper understanding of online tourism advertising messages on Croatians tourist boards websites, their structure and forms. The paper will serve as a point of reference for tourism and hospitality scholars, researchers and students interested in this topic. The research results are to be considered as a prerequisite for further detailed and systematic analyses from a multidisciplinary 
ToSEE - Tourism in Southern and Eastern Europe, Vol. 5, pp. 31-45, 2019

M. Bait, T. Baldigara, J. Komšić: WEB ADVERTISING MESSAGES IN CROATIAN TOURISM:

and multimodal perspective. In fact, the study should provide a contribution to the theoretical, empirical and managerial knowledge with various positive implication for all tourism service providers in creating a starting point for future more detailed and systematic researches and analyses of advertising messages efficiency, to encourage whole year tourism flows distribution and more effective decision-making.

\section{LITERATURE REVIEW}

Given the multidisciplinary (qualitative and quantitative) approach adopted to conduct the analysis of the advertising messages structures and forms, a comprehensive desk research and literature review have been carried out. The results showed that, in recent years, the issue of tourism advertising messages is becoming increasingly popular. The literature shows that there are several experimental studies that investigate forms, the features and the structure as well as the actual efficiency of advertising messages. In fact, given the interdisciplinary nature of the tourism domain, advertising messages have been investigated from various perspectives. The literature outline that follows considered only previous researches and experimental results that appeared to influence mostly the present research. Some of those results are mentioned below. In the field of marketing communication, researchers have focused on the language used in advertising as the wording possibilites can affect consumer behaviour and buying habits (Teodorescu, 2015).

In linguistics, the language of advertising has been analysed from various perspectives, e.g., as a genre by Bhatia \& Bhatia (2004), Garzone \& Gotti (2011) semiotically by Kress \& Van Leeuwen (1996), and Bärthes, (1977), or in terms of identity construction by Vasta, (2005) and (Piller, 2001).

Sentiment analysis or opinion mining is a type of text analysis method that aims to support decision-making by identifying negative and positive opinions and measuring how positively or negatively an entity or issue is perceived. In principle, sentiment is subjective feelings and includes people's attitude, emotions and opinions (Zhou et al., 2013).

Sentiment analysis has been popular since the early 2000 and several scholars in tourism research have recognised the need to find out what others are thinking and developed and applied sentiment analysis to tourism. Sentiment analysis in the tourism and hospitality field is mostly performed on customer hotel reviews (Pekar \& Ou, 2008; García-Pablos et al., 2016; Schmunk et al., 2013; Shi \& Li, 2011; Godnov \& Redek, 2016; Markopoulos et al., 2015), restaurant reviews (Zhang et al., 2016; Kang et al., 2012; Zhang et al., 2011), and destination reviews (García-Pablos et al., 2016; Ye et al., 2009; Bait et al., 2018)

Leech (1966) identified in his study four major functions of a successful advertisiement that influence the choice of language: attention, value, readability, memorability, and selling power. Furthermore, a group of researchers focused on the perceptions of destination advertising according to message appeal and endorsement type. Thus, Albers-Miller \& Royne Stafford, (1999) analyzed the emotional and rational appeals in 
ToSEE - Tourism in Southern and Eastern Europe, Vol. 5, pp. 31-45, 2019

M. Bait, T. Baldigara, J. Komšić: WEB ADVERTISING MESSAGES IN CROATIAN TOURISM: ...

services vs goods advertising and found that the experiential consumption of service and tourism products is more in line with emotions and feelings than factual information. Other findings have shown that emotional advertising works better when product evaluation is more subjective, or related to hedonic activites such as eating out at a restaurant, staying at a hotel or scheduling a vacation (Shostack, 1977). Wang et al. (2018) conducted a comparative study to investigate the differences in the advertising effectiveness of destination promotion by message appeal types and endorsement types to determine the most effective type of advertising for promoting a destination. The results have shown that message appeal and endorsement have been found to exhibit different advertising effects by varying types. Specifically, a rational as opposed to emotional advertisement appeal is more effective for U.S. tourists, whereas the reverse is true for mainland Chinese and Japanese tourists. Furthermore, Americans responded that advertising with an expert was perceived to be most trustworthy compared to the other attitudinal characteristics.

As tourism slogans are supposed to successfully communicate the unique values of a destination using a branding strategy and are a part of the national tourism promotion, the authors Huadhom \& Trakulkasemsuk (2017) applied a syntactic analysis of 100 online tourism slogans to investigate and analyse syntactic structures and characteristics frequently occurring in tourism slogans. Their findings show that noun phrases, simple declarative and imperative sentences were the most frequent syntactic forms, while the name of the countries was a mandatory element.

\section{METHODOLOGY}

The research methodology adopted in this study followed a three-stage procedure. In the first stage we focused on the selection and creation of the dataset, in the second stage we conducted the discourse analysis and finally, in the third stage we tried to summarize the research results outlining the most important findings.

The dataset of this study was downloaded from the official tourist boards of the main Croatian tourist regions in January 2019 (e.g. https://feeds.croatia.hr/hr/, www.istra.hr, http://www.infozagreb.hr, www.kvarner.hr, https://www.dalmatia.hr). The sample consists of 231 tourism advertising messages which are analysed by applying qualitative and quantitative research methodology. Before the analysis, a data cleaning process was performed in order to remove stopwords.

The discourse analysis was conducted on the collected advertising messages to identify salient linguistic traits which are shown as lexical, syntactical and rhetorical features. Furthermore, with the purpose of entering deeply into the structures and the form of analysed advertising messages and give a more complete insight into the discourse analysis a quantitative approach was used to examine the frequency and distribution of words in the advertising messages by using Tropses 8.4.4., an open source text base manager software for semantic analysis, which has "meaning making" functions and enables users to extract relevant discursive information. 
ToSEE - Tourism in Southern and Eastern Europe, Vol. 5, pp. 31-45, 2019

M. Bait, T. Baldigara, J. Komšić: WEB ADVERTISING MESSAGES IN CROATIAN TOURISM: ...

The sentiment analysis was applied to obtain information about the general mood of the advertising messages, i.e., to asses if the advertising messages were positive, neutral of negative. An open source tool was applied to perform the sentiment analysis (www.danielsoper.com/sentimetnanalysis/). The system computed a sentiment score which reflected the overall sentiment, tone or emotional feeling of the input text. Sentiment scores range from -100 to 100 , where -100 indicates a very negative or serious tone and 100 indicates a very positive or enthusiastic tone (Bait et al., 2018).

\section{FINDINGS}

Following the research methodology, in this part the most relevant findings are presented in this part of the paper. The presented research results and the main findings are described below.

\subsection{Qualitative analysis}

Within the language of tourism destination promotion three main functions are performed: the descriptive/informative and persuasive/promotional functions, as tourist destinations are similar to goods to sell, but also a strong emotional and evocative function. Texts seem to empower tourists to take autonomous and independent decisions about their travel choices, highlighting the concept of journey as freedom. Conversely, texts are aimed "to persuade, lure, woo and seduce millions of human beings, and, in doing so, convert them from potential into actual clients" (Dann, 1966: 2).

A careful choice of lexical items, syntactical structures, and rhetorical strategies can jointly work as the key to success of tourism destinations as it can trigger images reflecting the impressions and emotions associated with a destination that may be based on individual experiences or may emerge as 'induced' images (Gunn, 1972), or in MacCannel's words as a 'staged identity' (1973) of the destination, consciously created for promotional purposes.

This section discusses the linguistic characteristics of the advertising messages collected, with a view to identify and describe their salient traits and evaluate to what extent the advertising messages fulfil their primary persuasive purpose.

\subsubsection{Lexical features}

The first elements that are worth noting are uniqueness and richness in terms of magnificence of the location, historical heritage, but also modern amenities, as well as a wide range of possibilities for entertainment and sports activities. In fact, emphasis is laid on Croatia's winning role as the best destination all year round, as in the following examples:

(1) If your Mediterranean fantasies feature balmy days by sapphire waters in the shade of ancient walled towns, Croatia is the place to turn them into reality.

(2) You thought Tenerife was the ultimate biking terrace. Think closer. 
ToSEE - Tourism in Southern and Eastern Europe, Vol. 5, pp. 31-45, 2019

M. Bait, T. Baldigara, J. Komšić: WEB ADVERTISING MESSAGES IN CROATIAN TOURISM: ...

(3) Kopenhagen is known as the city of cyclists, and Istria holds the title of the peninsula of cyclists.

(4) ...how about family hikes in the countryside? Or days at sea, sailing with friends? Perhaps you have to put these pleasures on hold during the coldest and wettest months at home... Not in Croatia!

(5) Should UNESCO consider naming all of Croatia as world heritage?

Collecting this information, potential consumers create an 'image' or 'mental portrayal or prototype' of what the travel experience might be like. Such an image is generally based on attributes, expected benefits, and the symbolic meanings or psychological characteristics consumers associate with a specific destination. The described tourist location is always the most popular and most attractive. The language is very emphatic and strongly evaluative, extolling positive characteristics of the places described (Gotti, 2006: 27). The full use of evaluative terms in the texts analyzed is coherent with their promotional function: attractively describing and presenting the sights, as the following examples show: unforgettable holiday, amazing moments, magical escape, unique experience, beautiful places, etc.

The adverbial superlative most, and best help convey the exclusive quality of the destination, highlighting the strongly evaluative and therefore promotional character of texts:

(6) The most unusual attractions that just need to be discovered

(7) Visit places with the most beautiful sunrises

(8) Opatija ... The most romantic city in Europe.

The same concept is implied in excerpts (9), (10), and (11) below, where the use of superlatives heightens the fascination and uniqueness of the destination promoted:

(9) The Sweetest Part of the Adriatic

(10) Opatija. Destination with the longest tradition in tourism

(11) Experience nature finest destinations and feel like never before.

The uniqueness and authenticity of the places are also underlined by the verbs employed in the texts. The verb feel is widely present (Feel the colours; Feel the calm, etc.) to highlight that the travel experience becomes multisensory: tourists build up emotional arousals and mental multisensory imagery, either based on their real prior experiences, or on their virtual experiences, based on what they might expect to taste, hear, smell, see, or feel, as in the following:

(12) Eat like a local, feel like a local

(13) Taste Teran and find out why it was worshipped by the legendary Venetian lover Casanova and the Roman Empress Livia.

The verbs discover, explore, experience, enjoy, find, find out, see, visit, mainly expressed in the imperative form, suggest a fascinating exploration to which the tourist is lured and support the wealth of invitations and suggestions, provided by texts:

(14) Discover the places of the most chilling Istrian legends!

(15) Explore the Mysterious Frescoes of Tiny Istrian Churches. 
ToSEE - Tourism in Southern and Eastern Europe, Vol. 5, pp. 31-45, 2019

M. Bait, T. Baldigara, J. Komšić: WEB ADVERTISING MESSAGES IN CROATIAN TOURISM: ...

Through the frequent use of can and will tourists are given the possibility - and certainty - to explore the places described:

(16) You can bike across the entire region in one day.

On the other hand, must is not frequent and is occasionally used in nominalizations as in the following:

(17) Sailing in summer is never a maybe... but in autumn it's a must.

(18) Visiting Istria, the region with the best olive oils in the world, is a must for every true gourmand.

\subsubsection{Syntactic features}

On the syntactic plane, the most frequently occurred type of sentence structure is the declarative sentence consisting of a subject, preceding the verb, and basically giving statements:

(19) Your magical advent escape awaits you in Croatia

(20) No filter can beat Croatia's autumn sun.

However, some declarative sentences in the dataset lack both subject and a finite verb or have no predicator at all. These structures increase the declarative force of the sentence suggesting that the epistemic construction of the text cannot be questioned. Some examples are:

(21) Croatia full of life

(22) The Sweetest Part of the Adriatic

(23) A destination for all seasons.

Imperative sentences contain a verb in the imperative mood. Their concise, economical wording with a strong authoritative tone appeals to the potential tourists urging them to take advantage of the opportunities offered, as can be seen in examples (24) and (25):

(24) Take walks, ride a bicycle, kayak and surf with friends, and then relax in beach bars on the shore of the Cape Kamenjak.

(25) Take a leisurely stroll along extensive Istrian promenades by the sea, holding hands with your loved one. Let the rich nature and sunset inspire you to reveal romantic secrets.

The pragmatic purpose of the imperative is not that of commanding but rather to encourage the addressee to visit the particular destination. This involves the target tourist in a sort of pseudo-dialogue, introduces a strong interpersonal component (Halliday, 1994: 69-158) into the message implementing a dialogue between the writer, the tourist board, and the receiver, potential tourist, as indicated by (26) below:

$$
\text { Wander off on via Dinarica and you will find yourself. }
$$

Interrogative sentences ask a question and they end with a question mark. In fact, their function is not to question but to create again a strong interconnectedness with the readers. 
ToSEE - Tourism in Southern and Eastern Europe, Vol. 5, pp. 31-45, 2019

M. Bait, T. Baldigara, J. Komšić: WEB ADVERTISING MESSAGES IN CROATIAN TOURISM: ...

(27) Are you ready for glamorous camping? Experience the combination of modern luxury and stunning nature with glamping in Istria.

(28) You enjoy top quality wine? Are you looking for new flavours and scents? Come to Istria and reward your sophisticated palate with fresh wine aromas.

(29) Do you dream of experiencing the excitement of climbing natural rocks? Make this adrenaline dream come true in Istria!

(30) Are you tired of sitting in meetings and in front of the computer? Are you exhausted by difficult business decisions? Come to Istria and restore your energy!

These and similar questions outline a problem, a need, a desire, that is immediately solved or satisfied by the tourist board writer.

The ellipsis, questions, and direct commands build up the informal register and are involvement strategies that facilitate a sense of trust the tourist may feel for the operator, playing a helpful role (Maci, 2013: 189). The same formality is perceived by short exclamatory sentences through the use of commas and exclamation points, so that such sentences convey an enthusiastic tone, one that can build the reader/potential tourist's desire to join in:

(31) Action, baby!

(32) ... when you feel good, it shows.

(33) This place is electrifying!

(34) Ready, steady... go! Croatia has the ultimate challenge in store for you!

\subsubsection{Rhetorical features}

In order to be persuasive and influence personal choices about a destination, advertising tourism discourse should have "an attention value, obtained through both an appealing image (which may even be a surprising one), and the violation of some obvious rule of the language (spelling, phonetics, grammar, puns, jokes, metaphors, paradox) which allows the exploitation of persuasive strategies based on the use of rhetorical tropes, (Maci 2013: 141). As they are expressions systematically deviating from expectation, they succeed in communicating a multitude of meanings (Goddard, 1998), allowing advertisers to play with words and distort their literal meanings.

These rhetorical tools support and strengthen the advertising message making it memorable and, therefore, are extensively used in the dataset collected, as the following paragraphs will show.

Alliteration is a repetition of the same sounds at the beginning of words or stressed syllables, as in (35) and (36). Both excerpts show a pun because the former suggests the word dragonfly, while the latter plays with the double meaning of short holiday and type of wave:

Feel the fire inside: fly like a dragon

(36) Catch the Big Break! 
ToSEE - Tourism in Southern and Eastern Europe, Vol. 5, pp. 31-45, 2019

M. Bait, T. Baldigara, J. Komšić: WEB ADVERTISING MESSAGES IN CROATIAN TOURISM: ...

Consonance refers to repetitive sounds produced, usually in quick succession, by consonants within a sentence or phrase:

$$
\text { Pick a peak: these mountains are calling you! }
$$

Assonance is a repetition of vowel sounds within words and phrases to create rhythm:

$$
\text { Old but gold: five (pre-) historical artefacts you must see }
$$

Anaphora, is the repetition of a word or group of words in the beginning of successive clauses in the form of bicolon in example (39) and (40), and tricolon - and rhyme - in example (41):

(39) A thousand islands, a thousand things to do

(40) Eat like a local, feel like a local

(41) No noise, no roads, no cars - just you, the sea and the stars.

Antimetabole means repeating a phrase in reverse order:

$$
\text { Don't fill your life with days, fill your days with life }
$$

Metaphor is also an efficient tool in advertising messages. It does contribute to emphasizing the main idea describing, by comparison, one object in terms of another:
Wellness oasis.
A sea of opportunities.

Another strategy that appears to be exploited to its fullest extent in the dataset is intertextuality. It occurs when one text echoes or refers to another text in the wording of the advertising message. Familiar cultural phrases, sayings (45), or reference to music (46), film (46), (47), (48), books (49) etc. are generally used:

(45) Mens sana in corpore sano!

(46) Many rivers to cross: 6 rivers for an amazing adventure

(47) Some like it hot: why not go where the sun does shine?

(48) Do the Light Things: Choose a Lighthouse Just for Yourself

(49) The call of the wild in the valley of life

This device requires cultural understanding of the message, some knowledge allowing to recognize the reference merged in the new text. Example (49) recalls the title of Jack London's, but the second part shows another intertextual link to the Bible which might not be self-evident.

\subsubsection{Sentiment analysis}

The sentiment analysis was performed using a sentiment analyser (https://danielsoper.com/). Initially, the sentiment analysis was carried out on the original advertising messages with extracted stopwords. Then, before performing the second sentiment analysis on the same advertising message a data cleaning process was applied to remove stopwords, punctuation and numbers. 
ToSEE - Tourism in Southern and Eastern Europe, Vol. 5, pp. 31-45, 2019

M. Bait, T. Baldigara, J. Komšić: WEB ADVERTISING MESSAGES IN CROATIAN TOURISM: ...

Figure 1: Sentiment analysis of tourism advertising messages

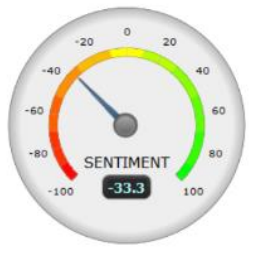

Results with excluded stopwords

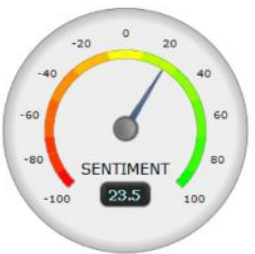

Reslts with exluded stopwords, punctuation, and numbers

Source: Research results

The results of the sentiment analysis have indicated a significant difference in the perception of advertising messages. The received sentiment score of the first analysis is -33.3. This means that the overall sentiment or tone of the advertising messages is somewhat negative/serious. The sentiment score of the second analysis is 23.5. This means that the overall sentiment or tone of the advertising messages is somewhat positive/enthusiastic. In both cases, much effort is needed to make the advertising messages more positive.

\subsection{Descriptive statistical analysis}

After performing the discourse analysis, a basic quantitative analysis was conducted using some simple elements in order to obtain a more complete overall picture of the research results. The performed basic descriptive analysis together with the discourse analysis results should provide insight into the present status of advertising, but more importantly, it should deliver some guidelines for further improvement and enhancement of the advertising messages potential.

The results of the quantitative data analysis were obtained by applying the Tropes 8.4.4. tool, which has extracted 13 most frequently used words categories: health, life \& casualties (107 equivalents), agriculture \& environment (89 equivalents), properties \& characteristics (84 equivalents), countries \& locations (76 equivalents), other concepts (63 equivalents), behaviours \& feelings (53 equivalents), numbers, time \& dates (39 equivalents), arts \& culture (26 equivalents), politics \& society ( 25 equivalents), things \& substances ( 21 equivalents), business \& industry (16 equivalents), nature \& wildlife (15 equivalents), and people and persons (12 equivalents). The analysed advertising messages, which encompass a wide spectrum of competitive and comparative advantages, mostly attract readers with messages related to hedonism, health, well-being, enjoyment, but also with natural attractions such as sea, beach, hills, wind, and sun. Advertising messages least aim to attract readers with historical famous persons and celebrities.

A more detailed analysis has revealed the top ten words used in the advertising messages and they are shown in Graph 1. 
ToSEE - Tourism in Southern and Eastern Europe, Vol. 5, pp. 31-45, 2019

M. Bait, T. Baldigara, J. Komšić: WEB ADVERTISING MESSAGES IN CROATIAN TOURISM: ...

\section{Graph 1: Most frequent words used in advertising messages}

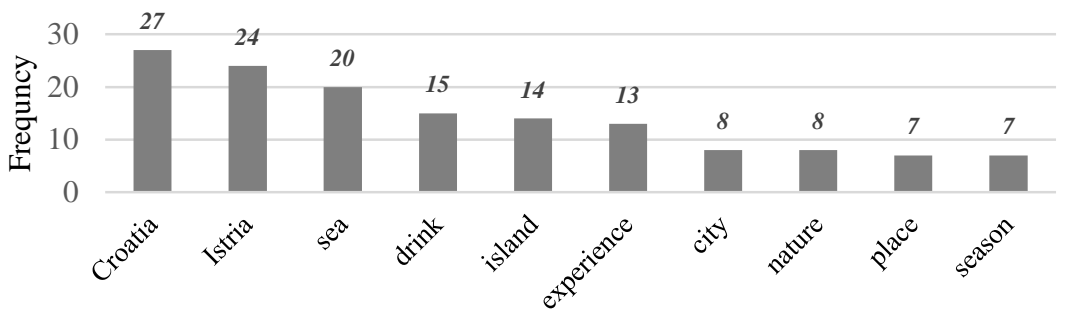

Words

Source: Research results

Compared to the previous qualitative lexical features results, the quantitative analysis confirms that the tourist locations (e.g. Croatia, Istria) are, with 76 occurrences, the most popular and frequent words used in the advertising messages, whereas the word experience is the favourite one when describing and presenting these locations.

Further, Wordcloud was used to better visualize the most frequent words. The greater the usage frequency of a word, the larger its presence in the wordcloud.

Figure 2: Wordcloud of the usage frequency of the words

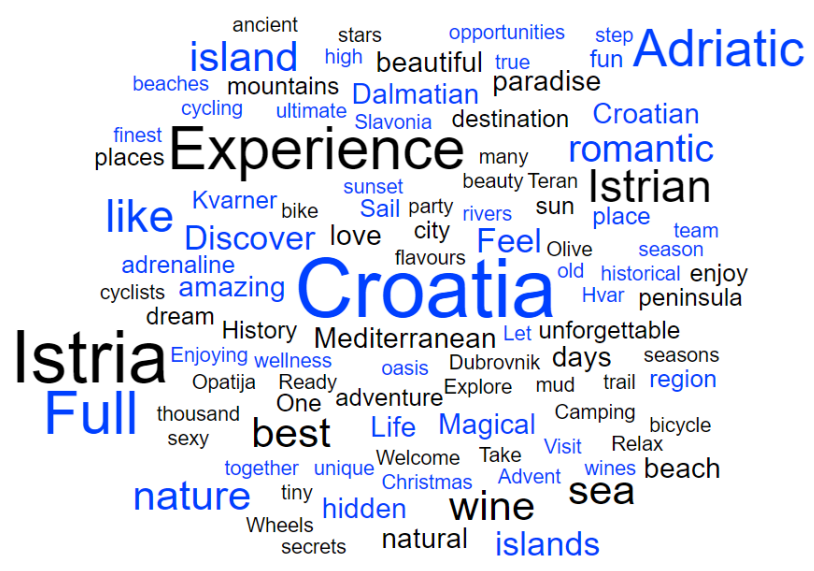

Source: Research results

In order to analyse the relationships between the applied words in the advertising messages, a star graph was applied. Broadly speaking, the star graph gives the number of relations (co-occurrence frequency) existing between the various references or between a word category and a reference. On the left of the central reference are its predecessors and those on the right its successors. This information is important because it allows the analysis of the strong relationship and associations (Rodrigues et al., 2014). 
ToSEE - Tourism in Southern and Eastern Europe, Vol. 5, pp. 31-45, 2019

M. Bait, T. Baldigara, J. Komšić: WEB ADVERTISING MESSAGES IN CROATIAN TOURISM: ...

Figure 3: Relationships between references displayed by star graphs
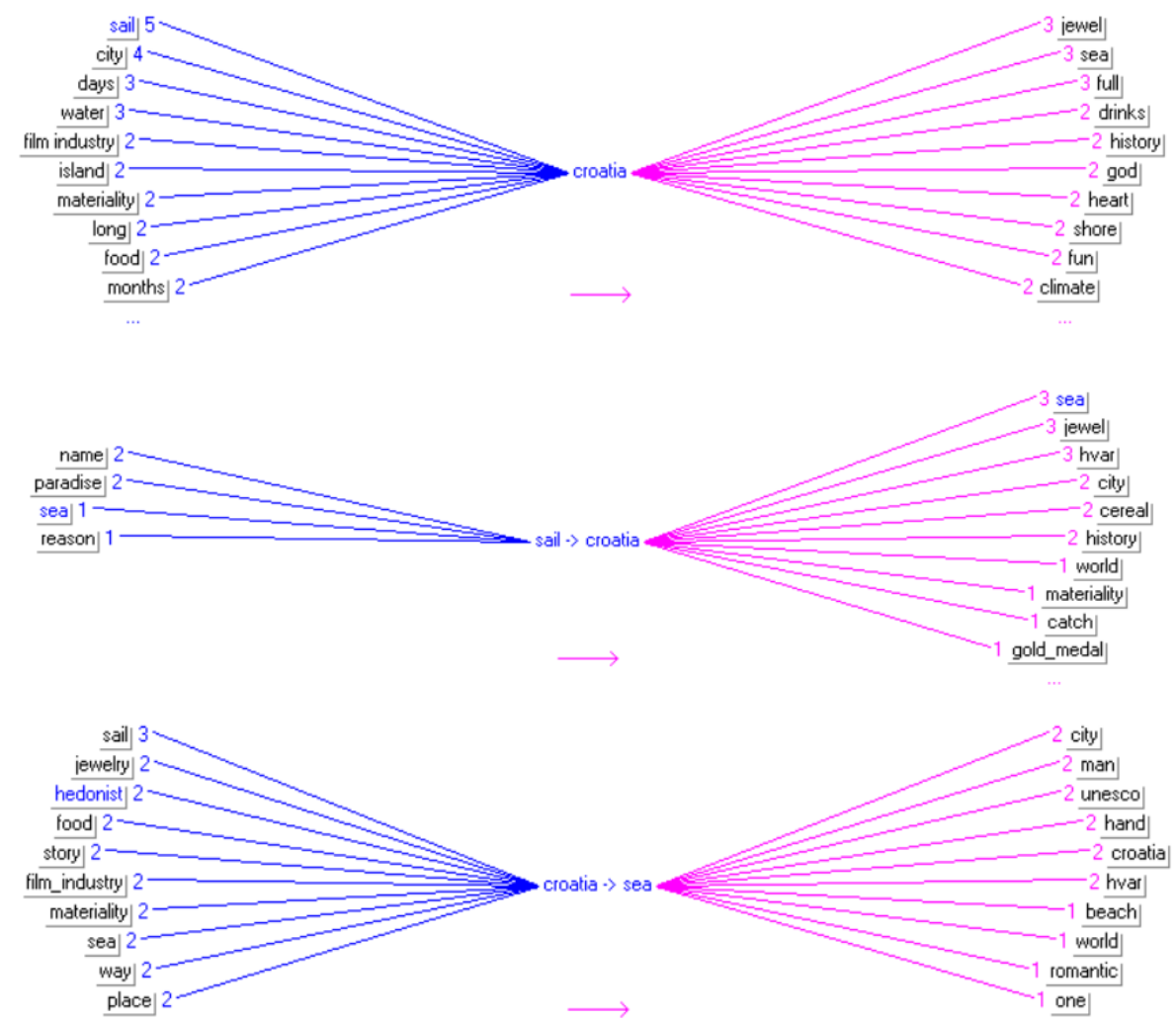

Sources: Research results

In chart graphs (Figure 3), Croatia represents the central reference because it appears most times in the advertising messages (27 times). Among the references, some are found to be more or less tightly connected. The tightest relationship (predecessor) to Croatia are sail, city, days, water, while jewel, sea, full, drinks, history represents the tightest successors of the relationships. As the reference sail appears three times relation to Croatia in the advertising messages, a relation connecting sail and Croatia is build. In general, Caution is required in the interpretation of these relations because some imaginary conclusion can be made. In conclusion, Croatia is strongly in relationship to its endowed resources (sea and nautical tourism) and gastronomy.

\section{CONCLUDING REMARKS AND FURTHER RESEARCH}

The qualitative analysis conducted on the advertising messages dataset has shown the presence of the typical traits of tourism advertising discourse: the syntactic structures and the lexical items in terms of adjectives and the verbal strategies make the text appear strongly evaluative and persuasive. 
ToSEE - Tourism in Southern and Eastern Europe, Vol. 5, pp. 31-45, 2019

M. Bait, T. Baldigara, J. Komšić: WEB ADVERTISING MESSAGES IN CROATIAN TOURISM: ...

Moreover, the texts' authors fully exploit rhetorical strategies typically belonging to the marketing field. Various linguistic techniques and figures of speech have been discussed here at phonological, lexical, syntactic and semantic levels.

The analysed advertising messages are more in line with emotions and feeling than information which could actually contribute to making tourism products tangible and more attractive to potential tourists. Competitive and comparative advantages both endow and create destination resources and are usually used in advertising messages to attract readers and sell tourism offers. The analysis results showed that most of the considered advertising messages are focused on attracting potential tourists during the main tourist season

From a linguistic point of view, the constructed discourse contributes to enhancing the attracting power of the destination and making it desirable for targeted receiver.

However, as advertising messages never appear without visual elements, further research should consider an integration of multimodal aspects into the study in order to obtain a comprehensive framework to assess effectiveness of the advertising messages. Specifically, readers' and tourists' perception of the advertising messages should be examined to obtain a fuller exploration of the destination promotion and identity, what will help destination marketing organisation to better promote and sell the tourism offer out of the main tourism season. Starting with the assumption, that advertising messages quality and the efficiency are vital elements in creating a successful tourism offer and a powerful tool of tourists' flow rerouting, tourism providers should make those messages more effective and capable to capture and increase tourism demand, as well as extend the country's appeal to the whole year.

\section{ACKNOWLEDGEMENTS}

This paper is the result of the scientific project „Tourism Providers advertising messages evaluation: A Multidisciplinary Perspective using Quantitative-Qualitative Approach“ which is supported by the University of Rijeka (Project No. ZP UNIRI 4/18).

\section{REFERENCES}

Albers-Miller, N.D., \& Royne Stafford, M. (1999), “An international analysis of emotional and rational appeals in services vs goods advertising”, Journal of Consumer Marketing, Vol. 16, No. 1, pp. 42-57 https://doi.org/10.1108/07363769910250769.

Bait, M., Jurin, S., \& Valković Bosnar, B. (2018), "Croatia as a virtual tourist destination: a linguistic and sentiment analysis". In Tourism \& Hospitality Insustry 2018 (pp. 1-18).

Baldigara, T., \& Mamula, M. (2012), "Tourism demand modelling and forecasting-a case study of Croatia". In Proceedings of the 6th International Conference Beyond the Economics Crisis: Lessons Learned and Challenges Ahead - ICES, pp. 906-920.

Bärthes, R. (1977), Image-Music-Text. In Image-Music-Text, Fontana, London.

Bhatia, V.K., \& Bhatia, A. (2004), "Global Genres in Local Contexts". In C. Candlin \& M. Gotti (Eds.), Intercultural Aspects of Specialized Communication, Peter Lang, Bern, pp. 263-281.

Dann, G. (1966), The Language of Tourism: A Sociolinguistic Perspective, CAB International, Wallingford. 
ToSEE - Tourism in Southern and Eastern Europe, Vol. 5, pp. 31-45, 2019

M. Bait, T. Baldigara, J. Komšić: WEB ADVERTISING MESSAGES IN CROATIAN TOURISM: ...

García-Pablos, A., Cuadros, M., \& Linaza, M. T. (2016), "Automatic analysis of textual hotel reviews", Information Technology \& Tourism, Vol. 16, No. 1, pp. 45-69 https://doi.org/10.1007/s40558-0150047-7.

García-Pablos, A., Duca, A.Lo, Cuadros, M., Linaza, M.T., \& Marchetti, A. (2016), "Correlating Languages and Sentiment Analysis on the Basis of Text-based Reviews". In Information and Communication Technologies in Tourism 2016, Springer International Publishing, Cham, pp. 565-577.

Garzone, G., \& Gotti, M. (2011), Discourse, Communication and the Enterprise: Genres and Trends, Peter Lang, Bern.

Geoffre, N.L. (1966), English in Advertising: Linguistic Study of Advertisement in Great Britain, Prentice Hall Europe, London, United Kingdom.

Goddard, A. (1998), The Language of Advertising, Routledge, London.

Godnov, U., \& Redek, T. (2016), "Application of text mining in tourism: Case of Croatia", Annals of Tourism Research, Vol. 58, pp. 162-166 https://doi.org/10.1016/j.annals.2016.02.005.

Gotti, M. (2006), "The Language of Tourism as Specialized Discourse”. In O. Palusci \& S. Francesconi (Eds.), Translating Tourism Linguistic/Cultural Representations, Università degli Studi di Trento, Trento, pp. $15-34$.

Gunn, Clare, A. (1972), Vacationscape: Designing Tourist Regions, Taylor \& Francis, Washington.

Halliday, M.A.K. (1994), An Introduction to Functional Grammar, Edward Arnold, London.

Huadhom, N., \& Trakulkasemsuk, W. (2017), "Syntactic Analysis of Online Tourism Slogans: Frequency, Forms and Functions", PASAA: Journal of Language Teaching and Learning in Thailand, Vol. 53, pp. 182-213.

Kang, H., Yoo, S.J., \& Han, D. (2012), "Senti-lexicon and improved Naïve Bayes algorithms for sentiment analysis of restaurant reviews", Expert Systems with Applications, Vol. 39, No. 5, pp. 6000-6010 https://doi.org/10.1016/J.ESWA.2011.11.107.

Kress, G.R., \& Van Leeuwen, T. (1996), Reading Images: The Grammar of Visual Design, Routledge, London.

MacCannell, D. (1973), "Staged Authenticity: Arrangements of Social Space in Tourist Settings", American Journal of Sociology, Vol. 79, No. 3, pp. 589-603.

Maci, S. M. (2013), Tourism Discourse. Professional, Promotional and Digital Voices, ECIG, Geneve.

Markopoulos, G., Mikros, G., Iliadi, A., \& Liontos, M. (2015), Sentiment Analysis of Hotel Reviews in Greek: A Comparison of Unigram Features. Springer, Cham, pp. 373-383.

Pekar, V., \& Shiyan Ou, S. (2008), "Discovery of subjective evaluations of product features in hotel reviews", Journal of Vacation Marketing, Vol. 14, No. 2, pp. 145-155 https://doi.org/10.1177/1356766707087522.

Piller, I. (2001), "Identity constructions in multilingual advertising” Language in Society, Vol. 30, No. 2, pp. 153-186.

Rodrigues, L.F., Costa, C.J., \& Oliveira, A. (2014), "Gamification: the using of user discussion groups in the software development in e-banking". In Proceedings of the International Conference on Information Systems and Design of Communication - ISDOC '14, ACM Press, New York, pp. 2734

Salehi, H., \& Farahbakhsh, M. (2014), "Tourism advertisement management and effective tools in tourism industry", International Journal of Geography and Geology, Vol. 3, No. 10, pp. 124-134.

Schmunk, S., Höpken, W., Fuchs, M., \& Lexhagen, M. (2013), "Sentiment Analysis: Extracting DecisionRelevant Knowledge from UGC", In Information and Communication Technologies in Tourism 2014, Springer International Publishing, Cham, pp. 253-265.

Shi, H.-X., \& Li, X.-J. (2011), "A sentiment analysis model for hotel reviews based on supervised learning". In 2011 International Conference on Machine Learning and Cybernetics, IEEE, pp. 950-954.

Shostack, G. L. (1977), "Breaking Free from Product Marketing”, Journal of Marketing, Vol. 41, No. 2, pp. 73-80 https://doi.org/10.2307/1250637.

Teodorescu, A. (2015), "Linguistic Patterns in Advertising Messages", Knowledge Horizons - Economics, Vol. 7, No. 3, pp. 115-118.

Vasta, N. (2005), "Profits \& Principles: Is There a Choice?" The Multimodal Construction of Shell's Commitment to Social Responsibility and the Environment in and across Advertising Texts. In G Cortese \& A. Duszak (Eds.), Identity, Community, Discourse, Peter Lang, Bern.

Wang, S., Kim, S. (Sam), \& Agrusa, J. (2018), "A comparative study of perceptions of destination advertising according to message appeal and endorsement type", Asia Pacific Journal of Tourism Research, Vol. 23, No. 1, pp. 24.41 https://doi.org/10.1080/10941665.2017.1394336.

Ye, Q., Zhang, Z., \& Law, R. (2009), "Sentiment classification of online reviews to travel destinations by supervised machine learning approaches", Expert Systems with Applications, Vol. 36, No. 3, pp. 6527-6535 https://doi.org/10.1016/J.ESWA.2008.07.035. 
ToSEE - Tourism in Southern and Eastern Europe, Vol. 5, pp. 31-45, 2019

M. Bait, T. Baldigara, J. Komšić: WEB ADVERTISING MESSAGES IN CROATIAN TOURISM:

Zhang, X., Yu, Y., Li, H., \& Lin, Z. (2016), "Sentimental interplay between structured and unstructured usergenerated contents", Online Information Review, Vol. 40, No. 1, pp. 119-145 https://doi.org/10.1108/OIR-04-2015-0101.

Zhang, Z., Ye, Q., Zhang, Z., \& Li, Y. (2011), "Sentiment classification of Internet restaurant reviews written in Cantonese", Expert Systems with Applications, Vol. 38, No. 6, pp. 7674-7682 https://doi.org/10.1016/J.ESWA.2010.12.147.

Zhou, X., Tao, X., Yong, J., \& Yang, Z. (2013), "Sentiment analysis on tweets for social events". In Proceedings of the 2013 IEEE 17th International Conference on Computer Supported Cooperative Work in Design (CSCWD), IEEE, pp. 557-562.

Miriam Bait, PhD, Assistant Professor

University degli Studi di Milano, Faculty of Humanities

Department of Philosophy

Via Festa del Perdono 7, 20122 Milano

Phone: + 390250312742

E-mail: miriam.bait@unimi.it

Tea Baldigara, $\mathrm{PhD}$, Full Professor

University of Rijeka

Faculty of Tourism and Hospitality Management

Department of Quantitative Economics

Primorska 42, P. O. Box. 97, 51410 Opatija

Phone: + 38551294684

E-mail: teab@fthm.hr

Jelena Komšić, PhD, Postdoctoral Researcher

University of Rijeka

Faculty of Tourism and Hospitality Management

Department of Quantitative Economics

Primorska 42, P. O. Box. 97, 51410 Opatija

Phone: + 38551294684

E-mail: jelenak@fthm.hr 